\title{
ANALISIS PENGUKURAN KINERJA PADA PEMERINTAH DAERAH
}

\section{PERFORMANCE MEASUREMENT ANALYSIS OF CITY GOVERNMENT}

\author{
A.B. Setiawan, C. Avrilivanni \\ Jurusan Akuntansi Fakultas Ekonomi Universitas Djuanda Bogor \\ E-mail: ade.budi.setiawan@unida.ac.id, clara21smu@gmail.com
}

\begin{abstract}
The purpose of this study is to determine the performance measurements implemented by the Bogor City Government and to determine the performance measurements using the balance scorecard approach. The research method uses data collection procedures by interview, field and literature study. The data used are primary and secondary data. Data analysis uses quantitative descriptive methods. The results of performance measurements implemented by the Bogor City Government are based on the Minister of Administrative Reform and Bureaucratic Reform Regulation No. 53 of 2014, in general the results of performance measurement are categorized as very good. Based on the balanced scorecard approach, it shows that in a financial perspective it is considered to be very economic, effective and less efficient. The customer perspective is very satisfied, the perspective of internal business processes is very good and the perspective of growth and learning is very good.
\end{abstract}

Keywords: Balance Scorecard, Customer, Financial, Internal Business Process, Learning Growth, Performance Measurement

\begin{abstract}
ABSTRAK
Tujuan dari penelitian ini untuk mengetahui pengukuran kinerja yang diterapkan oleh Pemerintah Kota Bogor dan untuk mengetahui pengukuran kinerja dengan pendekatan balance scorecard. Metode penelitian menggunakan prosedur pengumpulan data dengan cara wawancara, lapangan dan studi pustaka. Data yang digunakan adalah data primer dan sekunder. Analisis data menggunakan metode deskriptif kuantitatif. Hasil pengukuran kinerja yang diterapkan Pemerintah Kota Bogor didasarkan pada Peraturan Menteri Pendayagunaan Aparatur Negara dan Reformasi Birokrasi No 53 Tahun 2014, secara umum hasil pengukuran kinerja dikategorikan sangat baik. Berdasarkan pendekatan balance scorecard menunjukan bahwa dalam perspektif keuangan dinilai sangat ekonomi, efektif dan kurang efisien. Perspektif pelanggan sangat puas, perspektif proses bisnis internal sangat baik dan perspektif pertumbuhan dan pembelajaran sangat baik.
\end{abstract}

Kata Kunci: Balance Scorecard, Keuangan, Pelanggan, Pengukuran Kinerja, Pertumbuhan Pembelajaran, Proses Internal Bisnis 


\section{PENDAHULUAN}

Perkembangan akuntansi sektor publik di Indonesia mengalami kemajuan yang begitu pesat seiring dilaksanakannya otonomi daerah. Berdasarkan UndangUndang Nomor 23 Tahun 2014 tentang pemerintahan daerah dalam pasal 3 otonomi daerah adalah hak, wewenang, dan kewajiban daerah otonom untuk mengatur dan mengurus sendiri urusan pemerintahan dan kepentingan masyarakat setempat dalam sistem Negara Kesatuan Republik Indonesia.

Selain itu perkembangan yang sangat pesat juga membuat sebuah organisasi pemerintah untuk mewujudkan pemerintahan yang baik (good corporate governance). Berdasarkan tujuan, organisasi sektor publik berbeda dengan swasta. Sektor swasta tujuan utamanya untuk memaksimalkan laba sedangkan pada sektor publik tujuan utamanya untuk memberikan pelayanan kepada publik. Meskipun tujuan utama sektor publik adalah untuk memberikan pelayanan publik, namun sektor publik juga memiliki tujuan finansial. Karena untuk memberikan pelayanan publik membutuhkan dana. Dengan meningkatkan penerimaan negara, Pendapatan Asli Daerah (PAD), adalah contoh adanya tujuan finansial pada sektor publik Mardiasmo (2018:11).

Organisasi pemerintah diminta untuk memenuhi harapan berbagai kelompok stakeholders yaitu penerima layanan, karyawan, lembaga pemberi pinjaman maupun hibah, masyarakat dan pembayar pajak. Sektor publik memiliki tanggungjawab untuk menunjukan kemampuan bagaimana uang publik dibelanjakan secara ekonomis, efektif dan efisien. Ukuran finansial saja tidak cukup untuk menggambarkan kinerja sektor publik, karena sifat output yang di sektor publik lebih banyak bersifat intangible output. Oleh karena itu perlu dikembangkan ukuran kinerja nonfinansial (Mardiasmo 2018:152).

Akuntabilitas kinerja didasarkan pada Peraturan Presiden Nomor 29 Tahun 2014 tentang Sistem Akuntabilitas Kinerja Instansi Pemerintah, yang mewajibkan kepada setiap instansi pemerintah melakukan akuntabilitas kinerja masingmasing sebagai bentuk pertanggungjawaban dalam pencapaian tujuan organisasi sesuai tugas pokok dan fungsinya dalam bentuk laporan kinerja.

Berikut ini merupakan penilaian akuntabilitas kinerja Pemerintah Kota Bogor selama 2015-2018:

Tabel 1. Penilaian Akuntabilitas Kinerja Pemerintah Kota Bogor 2015-2018

\begin{tabular}{ccccc}
\hline No. & Tahun & Target & Realisasi & Skor \\
\hline 1. & 2015 & CC & CC & 56,04 \\
2. & 2016 & CC & CC & 57,89 \\
3. & 2017 & B & B & 62,44 \\
4. & $\mathbf{2 0 1 8}$ & BB & B & $\mathbf{6 7 , 4 3}$ \\
\hline
\end{tabular}

Sumber: Laporan Kinerja Pemerintah Kota Bogor 2018.

Berdasarkan data diatas merupakan penilaian akuntabilitas kinerja Pemerintah Kota Bogor selama kurun waktu empat tahun, dapat dilihat pada tahun 2015 - 2017 antara target dan realisasi dapat tercapai walaupun belum terdapat peningkatan skor yang signifikan. Sedangkan pada tahun 2018, tingkat akuntabilitas kinerja Pemerintah Kota Bogor mendapatkan predikat B dengan nilai 67,43. Predikat tersebut belum sesuai dengan target yang diharapkan yaitu pada tahun 2018 ditargetkan mendapat predikat BB. Hal ini yang mendasari penulis untuk melakukan pengukuran kinerja menggunakan pendekatan balance scorecard pada Pemerintah Kota Bogor.

Balance Scorecard adalah suatu pendekatan untuk mengukur kinerja yang akan menilai kinerja keuangan dengan 
kinerja non keuangan. Balanced Scorecard merupakan alat pengukuran kinerja yang mengintegrasikan good corporate governance Adawiyah dan Kusuma (2018). Balance Scorecard mulai diperkenalkan pada awal tahun 1990 di Amerika Serikat oleh Robert Kaplan dan David P. Norton melalui suatu riset tentang pengukuran kinerja dalam organisasi masa depan. Balance Scorecard terdiri dari empat perspektif yaitu perspektif keuangan, pelanggan, proses bisnis internal serta perspektif pembelajaran dan pertumbuhan.

Konsep Balance scorecard pada awalnya dimaksudkan untuk organisasi bisnis yang berorientasi pada profit namun pada perkembangannya balance scorecard juga dapat diterapkan pada organisasi sektor publik. Penerapan Balance Scorecard pada pengukuran kinerja organisasi publik bertujuan untuk menyatakan adanya keseimbangan antara berbagai ukuran internal dan eksternal. Untuk menerapkan Balance Scorecard pada sektor publik diperlukan modifikasi dikarenakan terdapat perbedaan antara Balance Scorecard untuk sektor publik dan sektor swasta, maka balance scorecard harus disesuaikan terlebih dahulu agar sesuai dengan kebutuhan organisasi publik.

Berbagai penelitian telah dilakukan untuk mengetahui kinerja instansi pemerintah dengan metode Balance Scorecard. Penelitian sebelumnya dilakukan oleh Amerieska dan Indrawan (2015) pada Kantor Perwakilan Pemerintah Provinsi Jawa Barat di Jakarta berkesimpulan bahwa secara keseluruhan kinerja termasuk kedalam kategori baik. Mahsina dkk (2017) menyatakan bahwa kinerja pada Dinas Pendapatan, Pengelolaan Keuangan, dan Aset Kabupaten Sidoarjo baik, berdasarkan perspektif pelanggan sudah mampu mengoptimalkan layanan untuk membantu masyarakat dengan membangun depo-depo pembayaran pajak. Dengan metode balanced scorecard kinerja perusahaan dari aspek non keuangan dapat diukur dan sebagai bahan evaluasi untuk membantu organisasi mencapai tujuan yang telah ditetapkan (Hasanah 2015).

\section{METODE PENELITIAN}

Objek penelitian ini adalah Pemerintah Kota Bogor yang meliputi seluruh Organisasi Perangkat Daerah yang berjumlah 37 OPD di Kota Bogor. Unit analisis dalam penelitian ini yaitu Pegawai masing-masing OPD dan masyarakat pengguna jasa layanan publik karena instansi pemerintah berorientasi meningkatkan pelayanan kepada masyarakat.

Penelitian ini adalah desain deskriptif. Anwar Sanusi (2016:13) desain penelitian deskriptif adalah desain penelitian yang disusun dalam rangka memberikan gambaran secara sistematis tentang informasi ilmiah yang berasal dari subjek atau objek penelitian.

Dalam melakukan penyusunan atas penelitian ini. Metode pengumpulan data penelitian yaitu :

1. Study Pustaka (library research)

Cara yang dilakukan penulis dalam pengumpulan data dilakukan dengan mempelajari buku-buku literatur yang berkaitan dengan bidang yang diteliti. Anwar Sanusi (2016:22) Studi kepustakaan diperoleh dari buku-buku teks, jurnal ilmiah, dan dari laporan hasil penelitian sebelumnya yang merupakan sumber paling potensial untuk menemukan masalah penelitian.

2. Study Lapangan (Field Research)

Penelitian lapangan adalah melakukan penelitian langsung ke objek yang akan diteliti. Penelitian lapangan dilakukan dengan cara mengumpulkan dokumentasi. Anwar Sanusi (2016:114) dokumentasi biasanya dilakukan untuk mengumpulkan data sekunder, baik secara pribadi maupun kelembagaan.

3. Wawancara

Penelitian dilakukan dengan wawancara tidak terstruktur, wawancara tidak tersktruktur merupakan wawancara bebas, peneliti tidak menggunakan pedoman wawancara yang telah tersusun 
secara sistematis dan lengkap untuk pengumpulan datanya. Sugiyono (2017: 140). Data dalam penelitian ini, data primer dan sekunder menggunakan metode analisis deskriptif kuantitatif.

\section{HASIL DAN PEMBAHASAN}

Kota Bogor merupakan sebuah kota di Provinsi Jawa Barat, Indonesia. Kota ini terletak $59 \mathrm{~km}$ sebelah selatan Jakarta, dan wilayahnya berada di tengah-tengah wilayah Kota Depok dan Kabupaten Bogor. Pengukuran Kinerja yang diterapkan oleh Pemerintah Kota Bogor bertitik tolak dari Rencana Pembangunan Jangka Menengah Daerah (RPJMD) Kota Bogor Tahun 20152019, Rencana Kerja Pemerintah Daerah (RKPD) Kota Bogor serta memperhatikan Peraturan Menteri Pendayagunaan Aparatur Negara dan Reformasi Birokrasi Nomor 53 Tahun 2014 tentang Petunjuk Teknis Perjanjian Kinerja, Pelaporan Kinerja dan Tata Cara Reviu atas Laporan Kinerja Instansi Pemerintah.

Pedoman pelaksanaan Penilaian Mandiri Pelaksanaan Reformasi Birokrasi (PMPRB) didasarkan pada Peraturan Menteri Pendayagunaan Aparatur Negara dan Reformasi Birokrasi Nomor 14 Tahun 2014 tentang Pedoman Evaluasi Reformasi Birokrasi Instansi Pemerintah. Berdasarkan hasil PMPRB pada tahun 2015-2016 indeks reformasi birokrasi belum terlaksana hal ini disebabkan adanya reviu mengenai sasaran, tujuan dan indikator sasaran. Reviu tersebut dilakukan dalam rangka perbaikan manajemen kinerja Pemerintah Kota Bogor sesuai dengan RPJMD, sehingga menghasilkan dokumen perencanaan yang memiliki arsitektur kinerja yang lebih fokus terhadap visi, misi, serta program prioritas pemerintah Kota Bogor. Hasil Indeks Reformasi Birokrasi pada tahun 2017 mencapai nilai 60,92 atau dengan predikat B. Pada komponen pengungkit/proses memperoleh nilai 41,15 dan pada komponen hasil memperoleh nilai 19,76. Pada tahun 2018 mencapai nilai 61,00 dengan predikat B. Pada komponen pengungkit/proses memperoleh nilai 31,10 dan pada komponen hasil memperoleh nilai 29,90 .

Selain itu Pemerintah Kota Bogor melaksanakan Indeks Kepuasan Masyarakat dengan berpedoman pada Peraturan Kementrian Pendayagunaan Aparatur Negara dan Reformasi Birokrasi Nomor 14 Tahun 2017. Hasil IKM pada tahun 2015 memperoleh nilai 3,1 dengan predikat Baik, tahun 2016 memperoleh nilai 3,2 dengan predikat Baik, tahun 2017 memperoleh nilai 3,21 dengan predikat Baik dan pada tahun 2018 mendapatkan nilai 3,31 dengan predikat Baik.

Berikut ini merupakan hasil pengukuran kinerja Pemerintah Kota Bogor menggunakan balance scorecard yang dilakukan oleh penulis:

Tabel 2. Hasil Rasio Ekonomi, Rasio Efisiensi dan Rasio Efektivitas Pemerintah Kota Bogor Tahun $2015-2018$

\begin{tabular}{ccccc}
\hline \multirow{2}{*}{ No. } & \multirow{2}{*}{ Tahun } & \multicolumn{3}{c}{ Tolok Ukur } \\
\cline { 3 - 5 } & 2015 & Ekonomi & Efisiensi & Efekivitas \\
\hline 1. & 2016 & $124,10 \%$ & $97,37 \%$ & $94,61 \%$ \\
2. & 2017 & $114,67 \%$ & $98,28 \%$ & $99,74 \%$ \\
3. & 2018 & $110,37 \%$ & $98,09 \%$ & $99,04 \%$ \\
4. & Rata-Rata & $\mathbf{1 1 6 , 2 0 \%}$ & $103,34 \%$ & $99,74 \%$ \\
\hline & & Sangat & $\mathbf{9 9 , 2 7 \%}$ & $\mathbf{9 9 , 5 3 \%}$ \\
\hline & Ekonomis & Efisien & Efektif \\
\hline
\end{tabular}

Sumber: Data Diolah 2019. 


\section{Perspektif Keuangan}

Berdasarkan tabel diatas hasil analisis kinerja perspektif keuangan dengan value for money adalah sebagai berikut:

\section{A. Rasio Ekonomi}

Rasio yang melihat kehematan penggunaan anggaran dan pengelolaan hemat serta tidak ada pemborosan. Pada tahun 2015 berada pada rasio 124,10\% dinilai sangat ekonomis, pada tahun 2016 tingkat rasio ekonomi mengalami penurunan dari $124,10 \%$ menjadi $114,67 \%$ dinilai sangat ekonomis, pada tahun 2017 mengalami kenaikan kembali dari 114,67\% menjadi $115,66 \%$ dinilai sangat ekonomis, dan pada tahun 2018 mengalami penurunan dari $115,66 \%$ menjadi $110,37 \%$ dinilai sangat ekonomis. Berdasarkan data pada tabel diatas, dapat diketahui bahwa kinerja Pemerintah Kota Bogor berdasarkan pengukuran rasio ekonomi mengalami fluktuatif. Hasil penilaian kinerja rasio ekonomi sesuai Keputusan Menteri Dalam Negeri Nomor 690.900.327 tahun 1996 mendapat kriteria penilaian sangat ekonomis. Hasil rekapitulasi selama empat tahun memperoleh nilai rata-rata keseluruhan sebesar 116,20\%. Dari tahun ke tahun pengeluaran Pemerintah Kota Bogor tidak pernah melampaui anggaran yang ditetapkan atau dengan kata lain realisasi pengeluaran (belanja daerah) selalu lebih kecil bila dibandingkan dengan anggaran yang telah ditetapkan Pemerintah Kota Bogor berhasil menekan biaya-biaya sehingga biaya yang terealisasi lebih kecil dibandingkan dengan biaya yang dianggarkan.

\section{B. Rasio Efektivitas}

Rasio yang menggambarkan berhasil tidaknya intitusi dalam mencapai tujuannya. Dalam hal ini adalah dengan membandingkan realisasi pendapatan dengan anggaran pendapatan yang telah ditetapkan. Pada tahun 2015 rasio efektifitas Pemerintah Kota Bogor sebesar 94,61\% dinilai efektif, tahun 2016 dinilai efektif dan mengalami kenaikan rasio efektivitas sebesar 513\% menjadi 99,74\%, tahun 2017 dinilai efektif namun kembali mengalami penurunan rasio sebesar $0,70 \%$ dari tahun sebelumnya menjadi $99,04 \%$. Pada tahun 2018 dinilai efektif dan kembali mengalami kenaikan pengukuran rasio efektivitas sebesar 0,70 menjadi $99,74 \%$. Selama periode empat tahun 2015-2018 kinerja rasio efektivitas Pemerintah Kota Bogor, tidak ada rasio yang berada diatas $100 \%$. Berarti setiap realisasi pendapatan tidak pernah mencapai rencana anggaran pendapatan.

Berdasarkan data tersebut diketahui bahwa kinerja Pemerintah Kota Bogor berdasarkan pengukuran rasio efektivitas sesuai Keputusan Menteri Dalam Negeri Nomor 690.900.327 tahun 1996 dinilai efektif dengan hasil pengukuran rasio selama empat tahun memperoleh nilai ratarata keseluruhan sebesar $99,53 \%$.

C. Rasio Efisiensi

Rasio untuk melihat seberapa efisien institusi mengelola pengeluaran untuk memperoleh pendapatan. Pada tahun 2015 sebesar $97,37 \%$ dinilai kurang efisien. Pada tahun 2016 rasio efisiensi mengalami kenaikan rasio $91 \%$ menjadi $98,28 \%$ dinilai kurang efisien, tahun 2017 mengalami penurunan rasio sebesar $19 \%$ menjadi 98,09\% dinilai kurang efisien. Selama tiga tahun terakhir 2015-2017 dinilai kurang efisien, namun sebaliknya pada tahun 2018 rasio efisiensi yang diperoleh Pemerintah Kota Bogor sebesar 103,34\% dinilai tidak efisien, dikarenakan total belanja daerah lebih besar dibandingkan total realisasi pendapatan (defisit anggaran) sebesar 77.883.504.174,19. Hal ini terjadi karena pada tahun 2018 pendapatan transfer dan pendapatan lain yang sah tidak mencapai target/realisasi. Kebijakan yang dilakukan oleh pemerintah kota bogor saat mengalami defisit yaitu dengan menggunakan sisa anggaran lebih (silpa) pada tahun sebelumnya.

Berdasarkan analisis data dapat diketahui bahwa kinerja Pemerintah Kota Bogor sesuai Kemengdagri Nomor 690.900.327 tahun 1996 mendapat kriteria penilaian rasio efisiensi kurang efisien. Hasil pengukuran rasio selama empat 
tahun, 2014 sampai dengan 2017 dinilai kurang efisien sedangkan tahun 2018 dinilai tidak efisien. Sehingga disimpulkan selama periode empat tahun memperoleh nilai rata-rata keseluruhan sebesar 99,27\%.

\section{Perspektif Pelanggan}

Pada perspektif pelanggan penulis melakukan survey kepuasan masyarakat kepada pengguna jasa layanan dari masing- masing OPD yang ada di Kota Bogor dengan jumlah 14 OPD. Survey dilakukan dengan berdasarkan pada pedoman Kepmenpan RB Nomor 14 tahun 2017. Teknik pengambilan sampel dilakukan dengan total sampling. Dari 14 OPD masing-masing 5, sehinggal total seluruh sampel adalah 70 kuesioner. Adapun hasil perspektif pelanggan adalah sebagai berikut:

Tabel 3. Rekapitulasi Skor Tanggapan Responden Perspektif Pelanggan

\begin{tabular}{|c|c|c|c|c|}
\hline Variabel & No & Pernyataan & Jawaban & Keterangan \\
\hline $\begin{array}{l}\text { Persyaratan } \\
\text { Pelayanan }\end{array}$ & 1. & $\begin{array}{l}\text { Persyaratan pelayanan (administrasi } \\
\text { dan teknis) yang ditetapkan telah } \\
\text { sesuai dengan jenis pelayanan yang } \\
\text { diberikan. }\end{array}$ & 4,30 & Sangat Setuju \\
\hline $\begin{array}{l}\text { Sistem, } \\
\text { Mekanisme, } \\
\text { Prosedur }\end{array}$ & $2 .$. & $\begin{array}{l}\text { Prosedur atau alur pelayanan yang } \\
\text { diberikan oleh pegawai mudah saya } \\
\text { ikuti (dalam melayani keperluan } \\
\text { masyarakat) }\end{array}$ & 4,36 & Sangat Setuju \\
\hline $\begin{array}{l}\text { Waktu } \\
\text { Penyelesaian }\end{array}$ & 3. & $\begin{array}{l}\text { Kecepatan pelayanan yang } \\
\text { diberikan oleh pegawai sudah } \\
\text { sangat baik dan selalu tepat waktu. }\end{array}$ & 4,16 & Setuju \\
\hline Biaya/Tarif & 4. & \begin{tabular}{lrrr} 
Biaya yang telah & dtetapkan oleh \\
instansi dalam & \multicolumn{2}{c}{ memberikan } \\
pelayanan sudah & wajar dan \\
terjangkau. & & & \\
& &
\end{tabular} & 4,76 & Sangat Setuju \\
\hline $\begin{array}{l}\text { Produk, } \\
\text { Spesifikasi, } \\
\text { Jenis Pelayanan }\end{array}$ & 5. & $\begin{array}{l}\text { Petugas dalam memberikan } \\
\text { pelayanannya sudah sesuai dengan } \\
\text { prosedur yang telah ditetapkan }\end{array}$ & 4,47 & Sangat Setuju \\
\hline $\begin{array}{l}\text { Kompetensi } \\
\text { Pelaksana }\end{array}$ & 6. & $\begin{array}{l}\text { Kemampuan petugas dalam } \\
\text { memberikan pelayanan pada } \\
\text { masyarakat sudah baik dan para } \\
\text { petugas memiliki keterampilan } \\
\text { dibidangnya }\end{array}$ & 4,50 & Sangat Setuju \\
\hline $\begin{array}{l}\text { Perilaku } \\
\text { Pelaksana }\end{array}$ & 7. & $\begin{array}{l}\text { Pegawai selalu memberikan } \\
\text { penanganan yang memuaskan dari } \\
\text { setiap pengaduan yang diajukan }\end{array}$ & 4,39 & Sangat Setuju \\
\hline $\begin{array}{l}\text { Penanganan } \\
\text { Pengaduan }\end{array}$ & 8. & $\begin{array}{l}\text { Pegawai selalu memberikan } \\
\text { penanganan yang memuaskan dari } \\
\text { setiap pengaduan yang diajukan }\end{array}$ & 4,34 & Sangat Setuju \\
\hline \multirow[t]{3}{*}{$\begin{array}{l}\text { Sarana dan } \\
\text { Prasarana }\end{array}$} & & $\begin{array}{l}\text { Lingkungan Badan/Kantor/Dinas } \\
\text { sangat nyaman dan mendukung } \\
\text { proses pelayanan masyarakat. }\end{array}$ & 4,45 & Sangat Setuju \\
\hline & & Total & 39,73 & \\
\hline & & Nilai rata-rata keseluruhan & 4,42 & Sangat Setuju \\
\hline
\end{tabular}

Sumber: Data Primer Diolah 2019.

Berdasarkan tabel 3. dapat diketahui jawaban responden untuk perspektif pelanggan, yaitu mengukur kepuasan masyarakat pengguna jasa layanan mulai yang terdiri dari 9 pernyataan sebagai berikut: 
1. Persyaratan pelayanan memperoleh nilai 4,30 dalam skala sangat setuju, hal ini berarti persyaratan yang telah diberikan telah sesuai dengan jenis pelayanan yang diberikan.

2. Sistem, mekanisme, prosedur memperoleh nilai 4,36 dalam skala sangat setuju, hal ini berarti Prosedur atau alur pelayanan yang diberikan oleh pegawai mudah dimengerti.

3. Waktu penyelesaian, memperoleh nilai 4,16 dalam skala setuju, hal ini berarti kecepatan pelayanan yang diberikan tidak selalu tepat waktu.

4. Biaya/tarif, memperoleh nilai 4,76 dalam skala sangat setuju, hal ini berarti biaya yang telah ditetapkan terjangkau.

5. Produk, spesifikasi, jenis pelayanan, memperolah nilai 4,47 dalam skala sangat setuju. hal ini berarti petugas dalam memberikan pelayanannya telah sesuai dengan produk yang telah ditetapkan.

6. Kompetensi Pelaksana, memperoleh nilai 4,50 dalam skala sangat setuju. hal ini berarti para petugas telah memiliki keterampilan dibidangnya.

7. Perilaku Pelaksana memperoleh nilai 4,39 dalam skala sangat setuju. hal ini berarti pegawai telah memberikan penanganan yang memuaskan dari setiap pengaduan yang diajukan.

8. Penanganan Pengaduan memperoleh nilai 4,34 dalam skala sangat setuju. hal ini berarti pegawai telah memberikan penanganan yang memuaskan dari setiap pengaduan yang diajukan.

9. Sarana dan Prasarana memperoleh nilai 4,45 dalam skala sangat setuju. hal ini berarti lingkungan pelayanan sangat nyaman dan mendukung proses layanan.

Nilai rata-rata tanggapan responden untuk perspektif pelanggan, yaitu mengukur kepuasan masyarakat pengguna jasa layanan sebesar 4,42 dalam skala sangat setuju. Pernyataan mengenai biaya/tarif, memiliki skor tertinggi mencapai 4,76 dalam skala sangat setuju. Hal ini berarti bahwa biaya yang ditetapkan dalam oleh instansi sudah sangat terjangkau, dengan kata lain tidak ada biaya yang harus dibayar karena sebagian besar biaya pelayanan ditanggung oleh pemerintah. Pernyataan mengenai waktu penyelesaian, memiliki skor terendah mencapai 4,16 dengan skala setuju. Hal ini berarti waktu penyelesaian pada instansi masih perlu diperbaiki agar waktu penyelesaian dalam pelayanan menjadi lebih cepat.

\section{Perspektif Proses Bisnis Internal}

Pada perspektif ini penulis memperoleh data melalui kuisioner disebarkan kepada pegawai kepala sub bagian umum dan kepegawaian dari masing-masing OPD di Kota Bogor. Kuesioner berjumlah 37, namun yang dapat diproses hanya 35 kuesioner. Berikut ini hasil rekapitulasi jawaban responden perspektif proses bisnis internal:

Tabel 4. Rekapitulasi Skor Tanggapan Responden Perspektif Bisnis Internal

\begin{tabular}{|c|c|c|c|c|}
\hline Variabel & No & Pernyataan & Jawaban & Keterangan \\
\hline \multirow[t]{7}{*}{ Wujud } & 1. & Kantor terletak pada lokasi yang strategis. & 4,12 & Setuju \\
\hline & 2. & Penampilan fisik gedung kantor baik. & 3,92 & Setuju \\
\hline & 3. & Tersedianya tempat parkir. & 4,03 & Setuju \\
\hline & 4. & Kebersihan \& kenyamanan ruang/gedung. & 4,09 & Setuju \\
\hline & 5. & $\begin{array}{l}\text { Kendaraan dinas yang mencukupi dan dalam } \\
\text { kondisi yang baik. }\end{array}$ & 4,03 & Setuju \\
\hline & 6. & Sarana telekomunikasi yang memadai & 4,40 & Sangat Setuju \\
\hline & & Nilai rata-rata variabel wujud & 4,09 & Setuju \\
\hline \multirow{2}{*}{$\begin{array}{l}\text { Kehandalan } \\
\text { (Reliability) }\end{array}$} & & $\begin{array}{l}\text { Pemberian layanan sesuai dengan prosedur } \\
\text { yang ditetapkan. }\end{array}$ & 4,35 & Sangat Setuju \\
\hline & 8. & Pegawai memahami prosedur pelayanan yang & 4,23 & Sangat Setuju \\
\hline
\end{tabular}


ada.

9. Ketersediaan data dan informasi yang dibutuhkan.

4,13 Setuju

10. Kemampuan pegawai dalam berkoordinasi. $4,18 \quad$ Setuju

11. Pegawai memiliki perhatian yang bak terhadap proses layanan.

4,23 Sangat Setuju

12. Pemberian layanan dengan adil. $4,26 \quad$ Sangat Setuju

\begin{tabular}{|c|c|c|c|}
\hline \multicolumn{2}{|c|}{ Nilai rata-rata variabel Kehandalan (Reliability) } & 4,23 & Sangat Setuju \\
\hline \multirow{3}{*}{$\begin{array}{l}\text { Daya } \\
\text { Tanggap } \\
\text { (Responsivene } \\
\text { s) }\end{array}$} & $\begin{array}{l}\text { 13. Tanggapan positif terhadap masalah yang } \\
\text { terjadi. }\end{array}$ & 4,35 & Sangat Setuju \\
\hline & $\begin{array}{l}\text { 14. Kesigapan pegawai dalam memberikan } \\
\text { bantuan kepada pengguna jasa layanan. }\end{array}$ & 4,32 & Sangat Setuju \\
\hline & $\begin{array}{l}\text { 15. Kemampuan pegawai dalam membantu } \\
\text { memecahkan permasalahan pengguna jasa } \\
\text { layanan. }\end{array}$ & 4,26 & Sangat Setuju \\
\hline \multicolumn{2}{|c|}{ Nilai rata-rata variabel Daya Tanggap (Responsivenes) } & 4,31 & Sangat Setuju \\
\hline \multirow{4}{*}{$\begin{array}{l}\text { Jaminan } \\
\text { (Assurance) }\end{array}$} & $\begin{array}{l}\text { 16. Pegawai bersikap ramah dan sopan dalam } \\
\text { menjalankan tugas. }\end{array}$ & 4,38 & Sangat Setuju \\
\hline & $\begin{array}{l}\text { 17. Pegawai memberikan data dan informasi } \\
\text { yang jelas. }\end{array}$ & 4,32 & Sangat Setuju \\
\hline & $\begin{array}{l}\text { 18. Kerampilan dan pengetahuan pegawai yang } \\
\text { memadai }\end{array}$ & 4,20 & Setuju \\
\hline & $\begin{array}{l}\text { 19. Jaminan keamanan, ketenangan, dan } \\
\text { kenyamanan dalam memberikan jasa } \\
\text { pelayanan. }\end{array}$ & 4,29 & Sangat Setuju \\
\hline \multicolumn{2}{|r|}{ Nilai rata-rata variabel Jaminan (Assurance) } & 4,29 & Sangat Setuju \\
\hline \multirow{4}{*}{$\begin{array}{l}\text { Empati } \\
\text { (Emphaty) }\end{array}$} & $\begin{array}{l}\text { 20. Kemudahan dalam menjalin hubungan yang } \\
\text { baik bila terjadi kesulitan dalam pekerjaan. }\end{array}$ & 4,23 & Sangat Setuju \\
\hline & $\begin{array}{l}\text { 21. Kemampuan berkomunikasi dengan baik } \\
\text { terhadap semua pihak. }\end{array}$ & 4,35 & Sangat Setuju \\
\hline & $\begin{array}{l}\text { 22. Tanggapan positif dalam menerima dan } \\
\text { memberikan informasi baru. }\end{array}$ & 4,40 & Sangat Setuju \\
\hline & $\begin{array}{l}\text { 23. Pemberian layanan sesuai dengan keinginan } \\
\text { semua pihak. }\end{array}$ & 4,35 & Sangat Setuju \\
\hline \multicolumn{2}{|r|}{ Nilai rata-rata variabel empati (Emphaty) } & 4,33 & Sangat Setuju \\
\hline \multicolumn{2}{|r|}{ Nilai rata-rata keseluruhan } & 4,31 & Sangat Setuju \\
\hline
\end{tabular}

Sumber: Data Primer Diolah 2019.

Berdasarkan tabel 4 diketahui rekapitulasi jawaban responden perspektif proses bisnis internal terdiri dari 23 pernyataan dengan 5 variabel berikut:

1. Variabel wujud

Tampilan fisik instansi dengan jumlah 6 pernyataan. Skor tertinggi mengenai sarana telekomunikasi yang memadai dengan skor 4,40 skala sangat setuju, skor terendah mengenai pernyataan penampilan fisik gedung mencapai 3,92 pada skala setuju. Hal ini diharapkan agar instansi memperbaiki penampilan fisik gedung.
Rata-rata skor keseluruhan variabel wujud adalah 4,09 dengan skala setuju.

2. Variabel kehandalan (reliability)

Kehandalan atau kemampuan organisasi dalam memberikan pelayanan dengan cepat terdiri dari 6 pernyataan. Skor tertinggi pernyataan pemberian layanan sesuai prosedur 4,35 skala sangat setuju, skor terendah ketersediaan data dan informasi dengan skor 4,13 skala setuju. Hal ini diharapkan agar instansi dapat menyediakan data dan informasi lebih detail agar dapat mendukung proses layanan dengan cepat. Rata-rata variabel kehandalan (reliability) 4,23 dengan skala sangat setuju. 
3. Variabel daya tanggap (responsiveness)

Terdiri dari 3 pernyataan, skor tertinggi pada pernyataan tanggapan positif terhadap masalah yang terjadi skor 4,35 skala sangat setuju, kemudian skor terendah pernyataan kemampuan pegawai dalam membantu memecahkan permasalahan pengguna jasa layanan skor 4,26. Rata-rata variabel daya tanggap (responsiveness) skor 4,31 dengan skala sangat setuju. Hal ini berarti bahwa sebagian besar responden berpendapat sangat setuju dan memiliki daya tanggap sangat baik pada saat melakukan pelayanan.

4. Variabel jaminan (assurance)

Terdiri dari 4 pernyataan. Pegawai bersikap ramah skor 4,38 skala sangat setuju, pegawai memberikan data dan informasi yang jelas skor 4,32 skala sangat setuju, keterampilan dan pengetahuan pegawai yang memadai skor 4,20 skala setuju, kemudian jaminan keamanan dan ketenangan skor 4,29 dengan skala sangat setuju. Rata-rata skor variabel jaminan (assurance) adalah 4,29 dengan skala sangat setuju. Hal ini berarti organisasi telah memberikan jaminan pelayanan sangat baik, karena sebagain besar responden berpendapat sangat setuju.

5. Variabel empati (emphaty)
Empati (emphaty) terdiri dari 4 pernyataan, kemudahan dalam menjalin hubungan skor 4,23 dengan skala sangat setuju, kemampuan berkomunikasi dengan semua pihak skor 4,35 dengan skala sangat setuju, tanggapan positif dalam menerima dan memberikan informasi baru skor 4,40 dengan skala sangat setuju, pemberian layanan sesuai dengan keinginan semua pihak skor 4,35 dengan skala sangat setuju. Rata-rata skor variabel empati adalah 4,33 dengan skala sangat setuju, hal ini berarti sebagian besar responden sangat setuju dengan kemampuan organisasi dalam memahami kebutuhan pelanggan.

Sementara itu nilai rata-rata tanggapan responden untuk perspektif proses bisnis internal, menunjukan sebagian besar responden menyatakan sangat setuju 4,31 dengan skala sangat setuju/sangat baik.

\section{Perspektif Pertumbuhan dan Pembelajan}

Perspektif pertumbuhan dan pembelajaran penulis memperoleh data melalui kuesioner yang dibagikan kepada kepala OPD yang ada di Kota Bogor. Kuesioner berjumlah 37, namun yang dapat diproses hanya 35 kuesioner. Berikut ini hasil rekapitulasi jawaban responden perspektif pertumbuhan dan pembelajaran:

Tabel 5. Rekapitulasi Skor Tanggapan Responden Perspektif Pertumbuhan \& Pembelajaran

\begin{tabular}{|c|c|c|c|c|}
\hline Variabel & No. & Pernyataan & Jawaban & Keterangan \\
\hline \multirow{5}{*}{$\begin{array}{l}\text { Kemampuan } \\
\text { Pegawai }\end{array}$} & 1. & Instansi secara rutin melaksanakan & 4,15 & Setuju \\
\hline & & $\begin{array}{l}\text { pelatihan pegawai. } \\
\text { Pegawai memenuhi standar kompetensi } \\
\text { (bermutu tinggi dan terlatih). }\end{array}$ & 4,15 & Setuju \\
\hline & 3. & $\begin{array}{l}\text { Pegawai disiplin dalam menjalankan } \\
\text { tugasnya. }\end{array}$ & 4,20 & Setuju \\
\hline & 4. & Pegawai selalu hadir tepat waktu. & 4,29 & Sangat Setuju \\
\hline & 5. & $\begin{array}{l}\text { Jabatan yang diberikan kepada pegawai } \\
\text { sesuai dengan kompetensinya. }\end{array}$ & 4,23 & Sangat Setuju \\
\hline \multicolumn{3}{|c|}{ Nilai rata-rata variabel kemampuan pegawai } & 4,21 & Sangat Setuju \\
\hline \multirow[t]{3}{*}{$\begin{array}{l}\text { Kualitas Sistem } \\
\text { Informasi }\end{array}$} & & $\begin{array}{l}\text { Tersedianya komputer dan internet untuk } \\
\text { mengakses informasi }\end{array}$ & 4,43 & Sangat Setuju \\
\hline & & $\begin{array}{l}\text { Pegawai rata-rata menguasai teknologi } \\
\text { yang akan membantu pekerjaan. }\end{array}$ & 4,20 & Setuju \\
\hline & 8. & $\begin{array}{l}\text { Informasi yang dibutuhkan tersedia dengan } \\
\text { cepat. }\end{array}$ & 4,35 & Sangat Setuju \\
\hline
\end{tabular}




\begin{tabular}{|c|c|c|c|c|}
\hline & 10. & $\begin{array}{l}\text { Sistem dibuat sedemikian rupa sehingga } \\
\text { dipastikan pegawai merespon pelanggan } \\
\text { tepat waktu. } \\
\text { Informasi yang dihasilkan sistem informasi } \\
\text { bisa diandalkan. }\end{array}$ & 4,29 & Sangat Setuju \\
\hline \multicolumn{3}{|c|}{ Nilai rata-rata variabel Kualitas Sistem Informasi } & 4,32 & Sangat Setuju \\
\hline \multirow{4}{*}{$\begin{array}{l}\text { Motivasi, } \\
\text { Inisiatif \& } \\
\text { Pendelegasian } \\
\text { Wewenang }\end{array}$} & 11. & $\begin{array}{l}\text { Setiap pegawai diberikan kesempatan } \\
\text { untuk menyampaikan pendapat dan saran } \\
\text { dalam pengambilan keputusan. }\end{array}$ & 4,23 & Sangat Setuju \\
\hline & 12. & $\begin{array}{l}\text { Pegawai diberi motivasi dalam } \\
\text { pengembangan kepribadian dan inisiatif } \\
\text { dalam bekerja }\end{array}$ & 4,26 & Sangat Setuju \\
\hline & 13. & $\begin{array}{l}\text { Hubungan kerja antara pimpinan dan } \\
\text { pegawai serta pegawai dan pegawai sangat } \\
\text { baik. }\end{array}$ & 4,32 & Sangat Setuju \\
\hline & 14. & $\begin{array}{l}\text { Pemberian wewenang yang diberikan } \\
\text { kepada pegawai sesuai dengan job } \\
\text { description. }\end{array}$ & 4,35 & Sangat Setuju \\
\hline \multicolumn{3}{|c|}{$\begin{array}{l}\text { Nilai rata-rata variabel Motivasi, Inisiatif \& Pendelegasian } \\
\text { Wewenang }\end{array}$} & 4,29 & Sangat Setuju \\
\hline \multicolumn{3}{|r|}{ Nilai Rata-Rata Keseluruhan } & 4,27 & Sangat Setuju \\
\hline
\end{tabular}

Sumber: Data Primer Diolah 2019.

Berdasarkan tabel 5 dapat diketahui hasil tanggapan responden perspektif pertumbuhan dan pembelajaran terdiri dari 14 pernyataan dengan 3 variabel berikut:

1. Variabel kemampuan pegawai

Terdiri dari 5 pernyataan. Instansi rutin melaksanakan pelatihan pegawai skor 4,15 dengan skala setuju, pegawai memenuhi standar kompetensi skor 4,15 dengan skala setuju, pegawai disiplin dalam menjalankan tugas skor 4,20 dengan skala setuju, pegawai selalu hadir tepat waktu skor 4,29 dengan skala sangat setuju, jabatan yang diberikan sesuai dengan kompetensinya skor 4,23 dengan skala sangat setuju. Berdasarkan data diatas skor tertinggi 4,29 pada instrumen pegawai selalu hadir tepat waktu, sedangkan skor terendah 4,15 pada instrumen instansi rutin melaksanakan pelatihan pegawai dan instrumen pegawai memenuhi standar kompetensi. Hal ini disimpulkan instansi diharapkan dapat meningkatkan pelatihan pegawai dan memperhatikan kompetensi pegawai, serta diharapkan dapat mempertahankan kedisiplinan pegawai yang selalu hadir tepat waktu. Rata-rata skor variabel kemampuan pegawai adalah 4,21 dengan skala sangat setuju.

2. Variabel kualitas sistem informasi

Terdiri dari 5 pernyataan. Pernyataan tersedianya komputer untuk mengakses informasi skor 4,43 dengan skala sangat setuju, pegawa rata-rata menguasai teknologi yang akan membantu pekerjaan skor 4,20 dengan skala setuju, informasi yang dibutuhkan tersedia dengan cepat skor 4,35 dengan skala sangat setuju, sistem dibuat sedemikian rupa sehingga dipastikan pegawai merespon tepat waktu skor 4,32 dengan skala sangat setuju informasi yang dihasilkan sistem bisa diandalkan skor 4,29 dengan skala sangat setuju. Berdasarkan data diatas skor tertinggi 4,43 pada instrumen tersedianya komputer untuk mengakses informasi, sedangkan skor terendah pada instrumen pegawai rata-rata menguasai teknologi yang akan membantu pekerjaan skor 4,20. Hal ini disimpulkan instansi diharapkan dapat memberikan pelatihan mengenai kompetensi pegawai agar dapat menguasai teknologi yang akan membantu pekerjaan. Rata-rata skor variabel kualitas sistem 
informasi adalah 4,32 dengan skala sangat setuju.

3. Variabel motivasi, inisiatif \& pendelegasian wewenang

Terdiri dari 4 pernyataan/instrumen. Skor tertinggi pada pernyataan pemberian wewenang yang diberikan kepada pegawai sesuai dengan job description 4,35 dengan skala sangat setuju, sedangkan skor terendah pada pernyataan setiap pegawai diberikan kesempatan untuk menyampaikan pendapat dan saran dalam pengambilan keputusan skor 4,23. Rata-rata skor variabel motivasi, inisiatif \& pendelegasian wewenang adalah 4,29 dengan skala sangat setuju.

Sementara itu nilai rata-rata tanggapan responden untuk perspektif proses pertumbuhan dan pembelajaran, menunjukan sebagian besar responden menyatakan sangat setuju 4,27 dengan skala sangat setuju/sangat baik.

5. Hasil Pengujian Instrumen

Hasil pangujian validitas dan reliabilitas perspektif pelanggan, perspektif proses bisnis internal, dan perspektif pertumbuhan dan pembelajaran dapat disimpulkan valid layak digunakan dan reliabel menunjukan konsistensi dan keterpercayaan hasil jawaban responden terhadap instrumen/pernyataan masingmasing perspektif.

6. Hasil Rekapitulasi Pengukuran Balance Scorecard

Hasil pengukuran kinerja menggunakan pendekatan balance scorecard disajikan pada tabel berikut:

Tabel 6. Rekapitulasi Hasil Pengukuran Kinerja dengan Pendekatan Balance Scorecard

\begin{tabular}{|c|c|c|c|}
\hline $\begin{array}{l}\text { Perspektif } \\
\text { Balance } \\
\text { Scorecard } \\
\end{array}$ & Variabel & $\begin{array}{c}\text { Hasil } \\
\text { Pengukuran }\end{array}$ & Kategori \\
\hline \multirow{3}{*}{$\begin{array}{l}\text { Perspektif } \\
\text { Keuangan }\end{array}$} & 1. Rasio Ekonomi 2015-2018 & $124,10 \%$ & Sangat Ekonomis \\
\hline & 2. Rasio Efektivitas 2015-2018 & $99,27 \%$ & Efektif \\
\hline & 3. Rasio Efisiensi 2015-2018 & $99,53 \%$ & Kurang Efisien \\
\hline $\begin{array}{l}\text { Perspektif } \\
\text { Pelanggan }\end{array}$ & $\begin{array}{c}\text { Survei Kepuasan Masyarakat tahun } \\
\text { berjalan } 2019\end{array}$ & 4,42 & $\begin{array}{l}\text { Sangat Setuju/ } \\
\text { Sangat Baik }\end{array}$ \\
\hline \multirow{6}{*}{$\begin{array}{l}\text { Perspektif } \\
\text { Proses Bisnis } \\
\text { internal }\end{array}$} & 1. Wujud & 4,09 & \\
\hline & 2. Kehandalan (Reliability) & 4,23 & \\
\hline & 3. Daya Tanggap (Responsiveness) & 4,31 & \\
\hline & 4. Jaminan (Assurance) & & \\
\hline & 5. Empati (Emphaty) & $\begin{array}{l}4,29 \\
4,33\end{array}$ & \\
\hline & Nilai rata-rata keseluruhan & 4,31 & $\begin{array}{l}\text { Sangat Setuju/ } \\
\text { Sangat Baik }\end{array}$ \\
\hline \multirow{4}{*}{$\begin{array}{c}\text { Perspektif } \\
\text { Pertumbuhan } \\
\text { dan } \\
\text { Pembelajaran }\end{array}$} & 1. Kemampuan Pegawai & 4,21 & \\
\hline & 2. Kualitas Sistem Informasi & 4,32 & \\
\hline & $\begin{array}{l}\text { 3. Motivasi,Inisiatif \& Pendelegasian } \\
\text { Wewenang }\end{array}$ & 4,29 & \\
\hline & Nilai rata-rata keseluruhan & 4,27 & $\begin{array}{l}\text { Sangat Setuju/ } \\
\text { Sangat Baik }\end{array}$ \\
\hline
\end{tabular}

Sumber: Hasil Olahan Peneliti 2019.

Berdasarkan tabel 6. disajikan hasil pembahasan sebagai berikut:

1. Perspektif keuangan

Kinerja keuangan berdasarkan kriteria penilaian Keputusan Menteri Dalam Negeri Nomor 690.900.327 tahun 1996 rasio ekonomis berada dalam kategori sangat ekonomis, selama kurun waktu 2015-2018 dengan perolehan nilai rata-rata $116,20 \%$ disimpulkan bahwa Pemerintah Kota Bogor berhasil menekan biaya-biaya sehingga biaya yang terealisasi lebih kecil dibandingkan dengan biaya yang dianggarkan. Berdasarkan rasio efektivitas 
berada dalam kategori efektif, selama kurun waktu 2015-2018 dengan perolehan nilai rata-rata $99,53 \%$. Berdasarkan rasio efisiensi berada dalam kategori kurang efisien, selama kurun waktu 2015-2018 dengan perolehan nilai rata-rata $99,27 \%$.

2. Perspektif pelanggan

Dilakukan dengan melakukan survei kepuasan masyarakat terdiri dari 9 pernyataan dengan menggunakan pedoman Keputusan Menteri Pendayagunaan Aparatur Negara Reformasi Birokrasi No: KEP/14/M.PAN/2017 nilai rata-rata tanggapan responden untuk perspektif pelanggan, yaitu mengukur kepuasan masyarakat pengguna jasa layanan sebesar 4,42 dalam skala sangat setuju, hal tersebut menunjukan sebagian besar responden menyatakan puas terhadap pelayanan yang telah diberikan.

3. Perspektif proses bisnis internal Mulai dari variabel wujud, kehandalan (reliability), daya tanggap (responsiveness), jaminan (assurance), dan empati (empathy) memperoleh nilai ratarata keseluruhan sebesar 4,31 dalam kategori sangat setuju/sangat baik hal ini berarti sebagian besar pegawai telah semaksimal mungkin dalam proses layanan internal.

4. Perspektif pertumbuhan dan pembelajaran

Mulai dari variabel kemampuan pegawai, kualitas sistem informasi, dan motivasi, inisiatif \& pendelegasian wewenang memperoleh nilai rata-rata keseluruhan sebesar 4,27 dalam kategori sangat setuju/sangat baik. Namun jika dilihat pada tabel tersebut variabel kemampuan pegawai memiliki nilai ratarata paling kecil yakni 4,21, Hal ini disimpulkan instansi diharapkan dapat meningkatkan pelatihan pegawai dan memperhatikan kompetensi pegawai. Nilai rata-rata terbesar pada variabel kualitas sistem informasi, dapat disimpulkan bahwa informasi tersedia dengan mudah.

\section{SIMPULAN DAN SARAN}

Dari hasil pembahasan dan penjelasan yang telah diuraikan, penulis mengambil kesimpulan sebagai berikut:

1. Pengukuran kinerja yang diterapkan Pemerintah Kota Bogor bertitik tolak dari Rencana Pembangunan Jangka Menengah Daerah (RPJMD) Kota Bogor Tahun 2015-2019, Rencana Kerja Pemerintah Daerah (RKPD) Kota Bogor serta memperhatikan Peraturan Menteri Pendayagunaan Aparatur Negara dan Reformasi Birokrasi Nomor 53 Tahun 2014 tentang Petunjuk Teknis Perjanjian Kinerja, Pelaporan Kinerja dan Tata Cara Reviu atas Laporan Kinerja Instansi Pemerintah. Secara umum Kinerja Pemerintah Kota Bogor dapat dikategorikan sangat baik.

2. Pengukuran kinerja Pemerintah Kota Bogor berdasarkan balance scorecard:

a) Perspektif keuangan berpedoman pada kriteria penilaian Keputusan Menteri Dalam Negeri Nomor 690.900.327 tahun 1996 untuk rasio ekonomi adalah sangat ekonomis, pengukuran rasio efektivitas efektif, sedangkan menurut rasio efisiensi dinilai kurang efisien.

b) Perspektif pelanggan berpedoman pada Keputusan Menteri Pendayagunaan Aparatur Negara Reformasi Birokrasi No: KEP/14/M.PAN/2017 nilai ratarata tanggapan responden sebesar 4,42 dalam skala sangat setuju, hal tersebut menunjukan sebagian besar responden menyatakan puas terhadap pelayanan yang telah diberikan.

c) Perspektif proses bisnis internal terdiri dari variabel wujud, kehandalan (reliability), daya tanggap (responsiveness), jaminan (assurance), dan empati (empathy) memperoleh nilai rata-rata 
keseluruhan sebesar 4,31 dalam kategori sangat setuju/sangat baik hal ini berarti sebagian besar pegawai telah semaksimal mungkin dalam proses layanan internal.

d) Perspektif pertumbuhan dan pembelajaran mulai dari variabel kemampuan pegawai, kualitas sistem informasi, dan motivasi, inisiatif \& pendelegasian wewenang memperoleh nilai ratarata keseluruhan sebesar 4,27 dalam kategori sangat setuju/sangat baik.

Berikut ini terdapat beberapa saran dan masukan yang disimpulkan dari penelitian ini:

1. Hasil keseluruhan pengukuran kinerja dengan balance scorecard dinilai sangat baik, sehingga perlu dipertahankan dan ditingkatkan pada tahun-tahun berikutnya.

2. Pada perspektif keuangan Pemerintah Kota Bogor disarankan untuk memperhatikan realisasi pendapatan dan realisasi pengeluaran dari tahun ke tahun karena pada tahun 2018 terdapat realisasi pengeluaran yang lebih besar dibandingkan dengan realisasi pendapatan.

\section{DAFTAR PUSTAKA}

Adawiyah, W., \& Kusuma, I. C. (2015). Analisis Kontribusi Dan Efektivitas Sumber-Sumber Pendapatan Asli Daerah Dan Dana Perimbangan Terhadap Anggaran Pendapatan Dan Belanja Daerah (APBD) Pemerintah Daerah Kota

Sukabumi. JURNAL AKUNIDA, 1(1), 17-26.

Amerieska, S., \& Indrawan, A. K. (2015). Pengukuran Kinerja Program e-Tax pada Pemerintah Kota Malang. SESINDO 2015, 2015.
Arisandi, Z. (2016). Analisis Pengukuran Kinerja Pelaksanaan Anggaran Belanja Dengan Value For Money Pada Dinas Pekerjaan Umum Bina Marga Dan Pengelolaan Sumber Daya Air Kota Palembang (Doctoral dissertation, Universitas Muhammadiyah Palembang).

Asfiansyah, A. (2015). Strategi implementasi akuntansi akrual Pada Pemerintah Daerah (studi kasus pada pemerintah kota "s"). $\mathrm{NeO}$ Bis, 9(1), 1-19.

Hasanah, U. U., \& Setiawan, A. B. (2018). Analisis Pengukuran Kinerja Sebelum Dan Sesudah Ditetapkannya Metode Balanced Scorecard Sebagai Tolok Ukur Pengukuran Kinerja. JURNAL AKUNIDA, 1(1), 9-16.

Langelo, F., Saerang, D. P. E., \& Alexander, S. W. (2015). Analisis penerapan standar akuntansi pemerintahan berbasis akrual dalam penyajian laporan keuangan pada pemerintah kota bitung. Jurnal EMBA: Jurnal Riset Ekonomi, Manajemen, Bisnis dan Akuntansi, 3(1).

Mutiha, A. (2016). Analisis Kinerja Keuangan Pemerintah Daerah Kota Bogor Tahun Anggaran 20102014. Jurnal Vokasi Indonesia, 4(2).

Pilat, J. J., \& Morasa, J. (2017). Analisis Rasio Keuangan Anggaran Pendapatan dan Belanja Daerah (APBD) Kota Manado untuk Menilai Kinerja Keuangan Pemerintah Kota Manado Tahun Anggaran 20112015. Jurnal Accountability, 6(1), 4556. 
Premananda, N. L. P. U., \& Latrini, M. Y. (2017). Pengaruh Akuntabilitas, Transparansi, dan Partisipasi Anggaran terhadap Kinerja Anggaran pada pemerintah kota Denpasar. E-Jurnal Akuntansi, 2451-2476.

Sartono, A., \& Tjahjono, A. (2018). ANALISIS PENGUKURAN

KINERJA KEUANGAN

PEMERINTAH DAERAH KOTA MAGELANG TAHUN 2012-2016 BERDASARKAN KONSEP VALUE FOR MONEY (Doctoral dissertation, STIE Widya Wiwaha).

Sajow, C., Morasa, J., \& Wokas, H. R. (2017). Analisis Realisasi Anggaran Belanja Daerah Pada Pemerintah Kota Tomohon Dan Pemerintah Kabupaten Minahasa Selatan. Jurnal EMBA: Jurnal Riset Ekonomi, Manajemen, Bisnis dan Akuntansi, 5(2).

Setiawan, A. B., \& Tami, R. P. (2018). Pengaruh Penerapan SAP Dan SPIP Terhadap Kualitas Laporan Keuangan Pemerintah Daerah Kota Bogor Dengan Kompetensi SDM Sebagai Variabel Moderating. JURNAL AKUNIDA, 4(1), 76-89.

Susanto, H. (2019). Analisis Rasio Keuangan Untuk Mengukur Kinerja Keuangan Pemerintah Daerah Kota Mataram. Jurnal Distribusi-Jurnal Ilmu Manajemen dan Bisnis, 7, 81-92.

Wahyuni, E. (2015). Pengaruh Budaya Organisasi Dan Gaya Kepemimpinan Terhadap Kinerja Pegawai Bagian Keuangan Organisasi Sektor Publik Dengan Motivasi Kerja Sebagai Variabel Intervening (Studi Kasus Pada Pegawai Pemerintah Kota Tasikmalaya). Nominal, Barometer Riset Akuntansi dan Manajemen, 4(1), 96-112.
Yusrianti, H., \& Henda Safitri, R. (2015). Implementasi Sistem Akuntabilitas Kinerja Instansi Pemerintah (SAKIP) Pada Satuan Kerja Perangkat Daerah (SKPD) Di Lingkungan Pemerintah Kota Palembang. Jurnal Manajemen dan Bisnis Sriwijaya, 13(4), 545-558.

Anwar, Sanusi. 2016. Metodologi Penelitian Bisnis. Cetakan Keenam. Jakarta: Salemba Empat.

Buku Pedoman Penulisan Skripsi. dan Karya Ilmiah. 2016. Fakultas Ekonomi: Universitas Djuanda Bogor.

Depdagri, Kementrian Pendayagunaan Aparatur Negara Nomor: 690.900.327 Tahun 1996 Tentang Pedoman Penilaian Kinerja Keuangan.

Fitria, Dinnar. 2016. Analisis Kinerja Dinas di Kota Bandung Dengan Metode Balance Scorecard (Studi Survey pada 17 Dinas Pemerintah Kota Bandung). Skripsi Tidak Dipublikasikan. Universitas Widyatama.

Hasanah, dan AB Setiawan. 2015. Analisis Pengukuran Kinerja Sebelum dan Sesudah Diterapkannya Metode Balance Scorecard Sebagai Tolok Ukur Pengukuran Kinerja. Universitas Djuanda. Jurnal Akunida ISSN 2442-3033 Vol.1, No1.

.2016. Menerapkan Strategi Menjadi Aksi Balance Scorecard. Terjemahan Peter R. dan Yosi Pasla. Jakarta: Erlangga.

Keputusan Menteri Pendayagunaan Aparatur Negara Nomor: KEP/14/M.PAN/2017 Tentang Pedoman Penyusunan Survei Kepuasan Masyarakat Unit Penyelenggara Pelayanan Publik. 
Keputusan Menteri Pendayagunaan Aparatur Negara Nomor: KEP/53/M.PAN/2014 Tentang Petunjuk Teknis Perjanjian Kinerja, Pelaporan Kinerja dan Tata Cara Reviu atas Laporan Kinerja Instansi Pemerintah.

Klaudius, Rondos. 2016. Analisis Penggunaan Metode Balance Scorecard untuk Menilai Kinerja Rumah Sakit (Studi Kasus pada Rumah Sakit Umum Daerah Sleman). Universitas Sanata Dharma. Skripsi.

Mardiasmo. (2018). Akuntansi Sektor Publik. Yogyakarta : ANDI.

Mahsina, dkk. 2017. Analisis Penerapan Balance Scorecard Alat ukur Penilaian Kinerja pada Dinas Pendapatan Pengelolaan Keuangan dan Aset Kabupaten Sidoarjo. Jurnal Maksipreneur, Vol. VII, No.1.

Sugiyono. 2017. Metode Penelitian Kualitatif, Kuantitatif dan R\&D. Alfabeta. Bandung.

\section{- 2018. Metode Penelitian Kualitatif, Kuantitatif dan R\&D. Alfabeta. Bandung.}

Peraturan Presiden Nomor 81 Tahun 2010 tentang Pelaksanaan Reformasi Birokrasi.

Peraturan Presiden Nomor 29 Tahun 2014 tentang Sistem Akuntabilitas Kinerja Instansi Pemerintah.

Pertani, Esa. 2018. Analisis Pengukuran Kinerja Organisasi Sektor Publik dengan Menggunakan Metode Balance Scorecard (Studi kasus di Dinas Pemuda, Olahraga, Kebudayaan dan Pariwisata Kabupaten Barito Timur, Kal-
Teng). Universitas Sanata Dharma. Skripsi.

Pitriani, Aprilia. 2014. Analisis Kinerja Melalui Balance Scorecard (Studi Kasus Dinas Pariwisata Provinsi Kepulauan Riau). Skripsi, Tidak Dipublikasikan, Fakultas Ekonomi, Universitas Maritim Raja Ali Haji.

Undang-Undang Republik Indonesia Nomor 23 Tahun 2014 tentang Pemerintahan Daerah.

http://www.kotabogor.go.id. (diakses pada tanggal 5 Agustus 2019).

http://id.wikipedia.org.Kota Bogor. (diakses pada tanggal 6 Agustus 2019). 